\title{
THE IMPACT OF DIVERSIFICATION OF REGIONAL ECONOMIC CONDITIONS ON THE ECONOMIC EFFICIENCY OF INTERMODAL TRANSPORT IN EUROPE
}

DATA PRZESŁANIA: 30.06.2016 | DATA AKCEPTACJI: 5.07.2016|KODY JEL: R3, 03

\section{Dariusz Milewski}

University of Szczecin

Faculty of Management and Economics of Services

e-mail: dariusz.milewski@wzieu.pl

\section{Bogusz Wiśnicki}

Maritime University of Szczecin

Transport Engineering and Economics Faculty

e-mail: b.wisnicki@am.szczecin.pl two different European regions, i.e. economically developed and developing countries. The authors identified determinants of technological and economic nature, which aim to achieve a desired economic efficiency of the intermodal transport. The economic imbalance of different regions in Europe refers to the following issues: the imbalance of the flows of cargo, lack of the uniform technological standards and differences in the economic environment. During the conducted research, authors analysed the cost of intermodal connections based on the use of three rail-road technologies dedicated to transport of semi-trailers. The analysed parameters included: distance of transport, mass of cargo, investment and operating costs. The calculations allowed would formulate conclusions and recommendations necessary for supporting conditions, which should be met, in order that the intermodal transport can effectively compete with the pure road transport.

intermodal transport, economic efficiency, transport costs 


\section{INTRODUCTION}

A large share of road transport in the European transport system in Europe has a serious problem from the point of view of the social costs. An alternative could be an intermodal transport, which combines the advantages of the different modes of transport and thus limits the harmful effects. Despite the different forms of public support, the intermodal transport failed to shift the expected amount of cargoes from roads to alternative transport modes. Particularly difficult is replacing pure road connections by intermodal door-to-door ones, i.e. rail-road services outside the most common seaport-hinterland scheme. The further analysis carried out by the authors concerns precisely this type of intermodal technology.

In order to measure the efficiency of the intermodal transport the right tools are needed. There are currently no effective research methods corresponding to the requirements of the complex and diverse economic intermodal transport system. There is also the problem of the application of the relevant criteria for evaluation of economic effectiveness. In addition to the traditional economic efficiency criteria of an investment, the macro-economic criteria should be also taken into account. This is justified by the fact that the intermodal transport market is supported with the help of transport policy tools. In the European Union the public support for the intermodal transport has the nature of the financial and non-financial contributions and is headed directly to the transport and logistics operators or to the owners of the transport infrastructure.

Central and Eastern Europe has its specific socio-economic conditions, deviating from the standards of Western Europe. The differences arise from the different structure of the market demand, the quality of infrastructure and transport policy tools. What differentiates transport markets in Europe greatly are the road transport freight rates, which are much lower in Eastern Europe. These rates may change as a result of pressure from the Western European countries to offset operating costs of road carriers in different European regions. This is a long-term strategy of the homogeneous conditions of transport operations in Europe, which is a part of the wider economic balance policy of the European Union.

The authors aim to examine the problem of inefficiency of intermodal connections that connect two economically different European regions, such as Western Europe on the one side and Central-Eastern Europe from the other side. Economic imbalances of these regions refer to the following issues:

- the imbalance of the cargo flows to be serviced by shuttle connections,

- the lack of uniform technological standards (different level of development of transport and transhipment technologies),

- differences in the economic environment, (average salary, freight rates, environmental awareness and industrialization).

Table 1 shows the most important factors determining the development of the intermodal transport in Central-Eastern Europe. Characteristic is a dominant role of seaports-hinterland connections, dedicated to global logistic chains realized in sea containers. Very few continental door-to-door connections are implemented in East-West relations, i.e. to and from large inland terminals and hubs in Western Europe. Therefore, intermodal units other than sea containers, i.e. swap bodies and semitrailers, are very rarely used.

In the following chapter, the cost analysis will be carried out of the West-East intermodal connections, on the basis of three alternative rail-road technologies with the use of semi-trailers. 
Table 1. Characteristics of intermodal transport in the Central-Eastern Europe

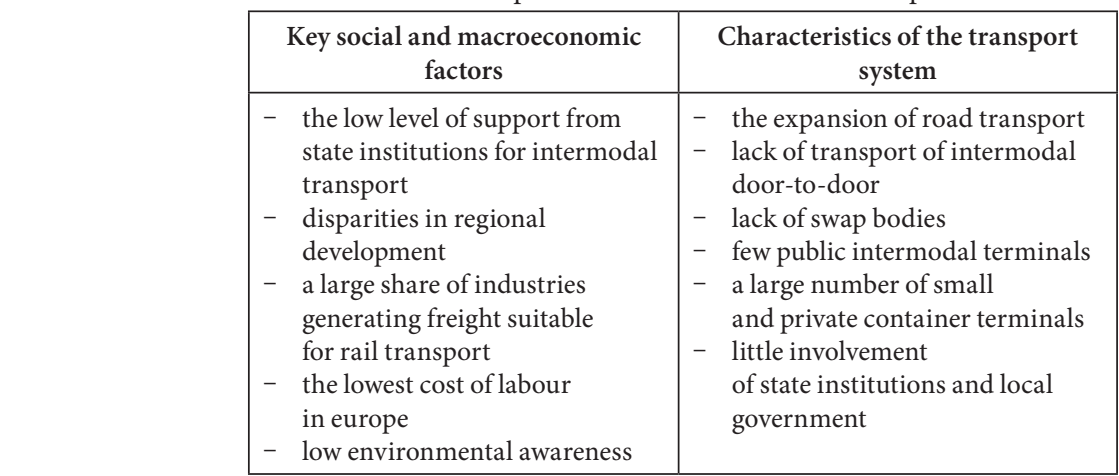

Source: own elaborations.

\section{LITERATURE REVIEW}

In the scientific literature a variety of identified reasons for the low share of intermodal transport in cargo transport can be found. It is believed that intermodal transport, in order to be competitive with road transport, requires a sufficiently large mass of cargo to carry and sufficiently long transport distances; in other words an appropriate scale. However, views on this subject are not consistent (Dărăbanț, Ștefănescu, Crișan, 2012; Zamkowska, 2013; Macharis, 2000; Vrenken, Macharis, Wolters, 2005; Arendt, Seidelmann, 2010), and what's more, they are not always confirmed by practice. According to the UIRR, the average distance of intermodal carriage was $932 \mathrm{~km}$ in 2014, and the most commonly used is piggy-back technology (UIRR Report, 2012).

Distance seems to be a very important factor in the efficiency of intermodal transport in Europe, the confirmation of which can be found in the work of Henttu and Multaharju (2011) and Arnold et al. (2004). The minimal distances of the cost-effectiveness of intermodal transport (500-600 km) given in the literature do not seem to be verified in practice. According to the UIRR in 2014, the average transport distance was $932 \mathrm{~km}$, but there were also shorter connections.

The influence of factors affecting economic efficiency depends largely on the cost structure. If we assume, however, that in fact the largest share of the total costs are the costs of the carriage, the question arises, which factors have a major influence on these costs? One explanation which arises at the current stage of research is that the boundaries of profitability depend on many factors among which the most important are: technology, policy fees for the use of transport infrastructure, and transport distance.

The results of the studies to date were often surprising. For example, studies conducted in Poland showed that the use of intermodal transport did not significantly allow a reduction in costs related to the choice of transport (Starzyńska, Walasek, 2013). These studies were conducted by questionnaire, however, and therefore it is difficult to assess by how much the statements of respondents are biased by subjective feelings, or whether they are based on actual cost data. Since the costs associated with the choice of modes of transport are significant in the cost of logistics enterprises, then why are there companies that opt for intermodal transport?

Very important factors of the economical effectiveness are the technical solutions (Nowakowski, Kwaśniowski, Zając, 2010; Krasoń, Niezgoda, 2013). The innovative technical solutions, the goal of which is to overcome the mentioned barriers of the intermodal transport development, 
(too small deliveries, over too short a distance for the intermodal technology) and to increase the time efficiency of the transport processes, help to a small extent in improving the attractiveness of this form of transport for its users. Perhaps the development of a method of the assessment of the economical effectiveness could help in searching for the effective solutions.

Among the research studies one can distinguish Study on unaccompanied combined transport of semitrailers through Switzerland, performer by the KombiConsult in the year 2012. The study contained the detailed comparative analysis of the three transport technologies of semitrailers by the rail transport. The research has been made for the transalpine relation and is based on the calculation of the costs of alternative technologies, which is "Piggyback", Modalohr and Cargobeamer. The first one is classified as the classic technologies, the two others as innovative and they have been invented to overcome barriers like relatively shorter distances of transport in Europe and high investment terminal costs. What's important, the authors of the KombiConsult's study conducted for each technology a cost structure and the method of cost calculation for the concrete case study of a transport connection between Cologne in Germany and Milan in Italy. It is a very valuable economic analysis, which shows the actual relationship between the key cost parameters characterizing intermodal transport technology.

Based on the research, carried out by the KombiConsult, it is possible to carry out further analysis adjusting the data and the calculation method to the specificity of the researched transportation connection and its market environment. Coming from this assumption, the authors of this paper undertook further analysis of intermodal connections between two differing economic regions in Europe. The analysis takes into account the traditional and innovative technologies, i.e. Modalohr and CargoBeamer, and its subject is the actual effectiveness of these technologies.

The elaborated model has rather hypothetical character. The existed intermodal links in Europe in many cases cover North-South routes. The analysis therefore concern situation of the higher than presently cooperation of Western and Eastern markets. In such a case the important role is played by the differences in the conditions of conducting businesses in different regions. This particularly applies to costs.

\section{MODEL OF EFFICIENCY OF THE INTERMODAL CONNECTION}

To examine the efficiency of the intermodal transport has been developed by the authors the model of the rail-road connection in the door-to-door European relationship, which consists of the following stages in the transport process:

- delivery of semitrailers from point of origin $\mathrm{O}$ to terminal A,

- transhipment in a terminal A,

- main transport (terminal A-terminal B) by intermodal train,

- transhipment in terminal B;

- delivery of semitrailers from terminal B to point of destination D;

The model is built from the perspective of an intermodal operator, who serves transport services for transport users. The operator establishes intermodal connection based on own assets and external services. The key own assets comprise transhipment terminals, intermodal wagons. Semitrailers are owned by the users of the intermodal connection. The basic cost and performance assumption of the model have been based on the study of KombiConsult (2012). This model has been adapted to the situation of diversity in economic development between the region where Terminal $\mathrm{A}$ is located and region of Terminal $\mathrm{B}$. The model has the form of a mathematical 
formula to calculate unit costs of intermodal transport of semitrailer in the door-to-door (O-D) relationship, taking into account the following connection parameters:

- 3 intermodal technologies: "Piggyback", Modalohr and Cargobeamer,

- 3 distances between terminals: $600 \mathrm{~km}, 800 \mathrm{~km}$ and $1000 \mathrm{~km}$,

- 3 different levels of cargo flows between terminals, assuming that in a shuttle connection train has minimum $80 \%$ utilisation in one direction and there are 4 different utilisation variants of return train: $80 \%, 60 \%, 30 \%$ and $0 \%$,

- differences in transhipment and road hauling costs between terminal A and B, measured in 3 cost proportions: 1,$0 ; 1,5 ; 2,0$,

- $25 \%$ margin on which prices are calculated.

This model stands for the modification of the KombiConsult's model, in which the assumptions complied with the transalpine freight market. An important difference is the expected number of pairs of trains servicing the intermodal connections. In the KombiKonsult study from 7 up to 16 pairs of trains was supposed to be running, depending on the technology in which the connection was made. In the author's opinion, for Eastern European countries it should be assumed 2 pairs of trains per each technology scenario. Of course, that should considerably impact the effectiveness of the whole transport connection.

The model of the total yearly costs of an intermodal connection by a given combination of technologies has following general mathematical form:

$$
T C=T C_{x-y}+T C_{y-x},
$$

where:

$T C_{x-y}$ - total yearly costs of an intermodal link between terminal $x$ and $y$,

$T C_{y-x}$ - total yearly costs of an intermodal link between terminal $y$ and $x$.

Total yearly costs of an intermodal link between terminal $x$ and $y$ are calculated as follow:

$$
T C_{x-y}=T C_{T I X}+T C_{H X}+T C_{F W X}+T C_{V W X}+T C_{H Y}+T C_{R T X-Y},
$$

where:

$T C_{T I X}$ - yearly fixed costs of terminal $x$ (depreciation costs),

$T C_{H X}$ - yearly variable costs of handling in both terminals taking into account load factor,

$T C_{F W_{X}}$ - yearly fixed costs of rail wagons (depreciation costs),

$T C_{V W X}$ - yearly variable costs of the carriage of rail wagons (traction costs) and maintenance costs, $T C_{R T X-Y}$ - yearly costs of the services of road transport service providers (pre-haulage from terminal $x$ and final delivery of consignments from terminal $y$ ).

The cost components are calculated with the use of formulas below:

$$
T C_{H X}=C O_{X} * N o_{S T X},
$$

where:

$\mathrm{CO}_{X}$ - operational costs (costs of one transshipment operation) in terminal $x$, $N o_{S T \rightarrow X}$ - number of semitrailers reloaded at terminal $x$ and sent to terminal $y$.

Variable costs of rail transport from $x$ to $y$

$$
T C_{V W X}=\left(C_{T R X} * * D_{X-Y}+C_{S T r X}\right) * N o_{T R X} * N o_{O D X},
$$


where:

$C_{T R X}$ - traction costs,

$D_{X-Y}$ - distance between terminals,

$C_{S T r_{X} X}-$ cost of the service of a train (service per journey),

$N o_{T R X}$ - number of trains in a given technology in terminal per one day sent terminal $x$ to terminal $y$,

$N o_{O D X}$ - number of operational days.

Costs of road transport services are the sum of pre-haulage to $x$ and final delivery from $y$

$$
\begin{gathered}
T C_{R T X-Y}=T C_{R T \rightarrow X}+T C_{R T \rightarrow Y} \\
T C_{R T \rightarrow X}=T C_{R T \rightarrow Y}=N o_{S T \rightarrow X} * D_{X-Y} * F r_{\rightarrow X},
\end{gathered}
$$

where:

$F r_{\rightarrow X}$ - freight rate of transporting one semitrailer to terminal $x$.

Summary of key input data for the calculations describing the analysed transport connection are shown in tables $2-4$. Costs, which are used in calculations are fixed and variable and this classification generally corresponds with the classification on indirect and direct costs. The fixed and indirect costs are first of all costs linked with investments in terminals and rail wagons. The depreciation costs in table 3 are calculated on the base of investments expenditures and life time of equipment - 13 years for terminals and 20 for rail wagons.

Table 2. Technological data for calculations

\begin{tabular}{|l|c|c|c|c|}
\hline \multirow{2}{*}{ Technologies } & $\begin{array}{c}\text { Max. No } \\
\text { of semitrailers }\end{array}$ & \multicolumn{2}{|c|}{ Capacity of trains } & $\begin{array}{c}\text { Pairs of trains } \\
\text { per terminal } \\
\text { [trains/day] }\end{array}$ \\
\cline { 2 - 5 } & [units] & load. factor [\%] & load. factor [units] & 2 \\
\hline "Piggy back" & 40 & 80 & 32,0 & 2 \\
\hline $\begin{array}{l}\text { Modalohr } \\
\text { Horizontal }\end{array}$ & 37 & 80 & 29,6 & 2 \\
\hline CargoBeamer & 30 & 80 & 24,0 & 2 \\
\hline
\end{tabular}

Source: own elaborations of the base of UIRR Report (2012).

Table 3. Economical data for calculations

\begin{tabular}{|l|c|c|c|c|}
\hline \multirow{2}{*}{ Technology } & \multicolumn{2}{|c|}{ Transhipment costs } & \multicolumn{2}{c|}{ Costs of Wagons } \\
\cline { 2 - 5 } & $\begin{array}{c}\text { yearly depreciation } \\
\text { of a terminal }\end{array}$ & $\begin{array}{c}\text { operational } \\
\text { costs }\end{array}$ & $\begin{array}{c}\text { depreciation } \\
\text { costs }\end{array}$ & $\begin{array}{c}\text { maintenance } \\
\text { costs }\end{array}$ \\
\hline "Piggy back" & 2461538 & 16 & 70000 & 3150 \\
\hline $\begin{array}{l}\text { Modalohr } \\
\text { Horizontal }\end{array}$ & 1461538 & 16 & 175000 & 14000 \\
\hline CargoBeamer & 1884615 & 16 & 140000 & 11200 \\
\hline
\end{tabular}

Source: own elaborations of the base of UIRR Report (2012). 
Table 4. Operational data for calculations

\begin{tabular}{|l|c|}
\hline Distances between terminals $[\mathrm{km}]$ & $600,800,1000$ \\
\hline Traction costs [€/train/km] & 14,5 \\
\hline Service of a train [€/journey] & 500 \\
\hline Number of operational days in a year & 300 \\
\hline Distance to and from a terminal $[\mathrm{km}]$ & 150 \\
\hline Freight rate of a road carrier [EUR/km] & 1,5 \\
\hline
\end{tabular}

Source: own elaborations of the base of UIRR Report (2012).

\section{RESULTS OF THE STUDIES}

The results of the model calculations are presented in tables 5-8. Taking into consideration, that presently the average freight rate of road transport in the Eastern Europe is $1,00 € /$ semitrailer $/ \mathrm{km}$, the unit freight rate for an intermodal service should be minimum $15 \%$ lower, i.e. it should be not above $0,85 € /$ semitrailer/km (Wiśnicki, Milewski, 2014). This price could be achieved only in case of the "Piggy back" system, assuming minimum $60 \%$ train's utilization level for return trains (Table 5). Other technologies are not competitive in any case. Below $60 \%$ level of utilisation of return trains, all technologies are not profitable or would require state support. That means that utilization plays a very important role for economical effectiveness. The main factor of the high effectiveness of "Piggy back", despite the highest terminal investment costs, is probably higher productivity, because in this technology the biggest number of semitrailers can be carried. On the other hand, however, the investment costs of wagons are the lowest here, but wagon costs don't stand for the biggest share of the total costs.

Table 5. The influence of the degree of the balance of flows of cargoes on prices of an intermodal operator $[€ /$ semitrailer $/ \mathrm{km}]$

\begin{tabular}{|l|c|c|c|c|}
\hline $\begin{array}{c}\text { The degree } \\
\text { of a balance of flows }\end{array}$ & $\mathbf{8 0 \%}$ & $\mathbf{6 0 \%}$ & $\mathbf{3 0 \%}$ & $\mathbf{0 \%}$ \\
\hline "Piggy back" & 0,77 & 0,85 & 1,02 & 1,34 \\
\hline Modalohr Horizontal & 1,02 & 1,13 & 1,39 & 1,84 \\
\hline CargoBeamer & 1,04 & 1,16 & 1,42 & 1,88 \\
\hline
\end{tabular}

Source: own elaborations of the base of UIRR Report (2012).

Table 6. The influence of the differences of costs of regions on prices of an intermodal operator [€/semitrailer $/ \mathrm{km}]$

\begin{tabular}{|l|c|c|c|c|}
\hline \multicolumn{1}{|c|}{ The costs relations } & $\mathbf{1 , 0}$ & $\mathbf{1 , 5}$ & $\mathbf{2 , 0}$ & $\mathbf{1 , 0}$ \\
\hline "Piggy back" & 0,77 & 0,70 & 0,67 & 0,77 \\
\hline Modalohr Horizontal & 1,02 & 0,95 & 0,92 & 1,02 \\
\hline CargoBeamer & 1,04 & 0,96 & 0,92 & 1,04 \\
\hline
\end{tabular}

Source: own elaborations of the base of UIRR Report (2012).

The prices could be considerably lower if terminal, transhipment and road costs were lower in the Eastern part of an intermodal chain (rail costs are not changeable). But still "Piggy back" remains the cheapest option (Table 6). 
There can be a situation, when, on both sides of an intermodal connection, different technologies are used. The reasons can be, for example: investments in different periods, level of available funds for investments in different countries and a policy of a country which prefers a certain technology. The cheapest combination, when different systems are used it is "Modalohr Horizontal - Piggy back" (Table 7).

In the general opinion the scale of operation is the important factor of the economical effectiveness of intermodal transport. Scale can be referred in this case to the distance of transport, the length of trains, number of trains in a given period and the utilization of trains.

Table 7. The influence of a technology used on prices of an intermodal operator [EUR/semitrailer $/ \mathrm{km}$ ]

\begin{tabular}{|l|l|l|}
\hline $\begin{array}{c}\text { Technology } \\
\text { in a Western terminal }\end{array}$ & \multicolumn{1}{c|}{$\begin{array}{c}\text { Technology } \\
\text { in a Eastern terminal }\end{array}$} & $\begin{array}{c}\text { Prices } \\
\text { of an intermodal operator } \\
\text { [EUR/semitrailer/km] }\end{array}$ \\
\hline Modalohr Horizontal & Modalohr Horizontal & 0,95 \\
\hline Modalohr Horizontal & "Piggy back" & 0,84 \\
\hline CargoBeamer & CargoBeamer & 0,96 \\
\hline CargoBeamer & "Piggy back" & 0,91 \\
\hline "Piggy back" & "Piggy back" & 0,70 \\
\hline
\end{tabular}

Source: own elaborations of the base of UIRR Report (2012).

The distance of transport doesn't seem to have great impact on the effectiveness in comparison to the previous factors (Table 8). Explanation to that and quite a surprise is that the level of fixed costs was not so high in the calculations as it may seem. Even on shorter distances the share of fixed costs is from 48 to $60 \%$. On the distance of $1000 \mathrm{~km}$ fixed costs are even lower than variable ones in case of "Piggy back" and CargoBeamer.

Table 8. The influence of a length of an intermodal connection on prices of an intermodal operator [€/semitrailer/ $\mathrm{km}$ ]

\begin{tabular}{|l|l|l|l|}
\hline \multicolumn{1}{|c|}{ Distance $[\mathrm{km}]$} & \multicolumn{1}{|c|}{$\mathbf{6 0 0}$} & \multicolumn{1}{c|}{$\mathbf{8 0 0}$} & \multicolumn{1}{c|}{$\mathbf{1 0 0 0}$} \\
\hline "Piggy back" & 0,92 & 0,79 & 0,71 \\
\hline Modalohr Horizontal & 1,25 & 1,06 & 0,93 \\
\hline CargoBeamer & 1,26 & 1,08 & 0,96 \\
\hline
\end{tabular}

Source: own elaborations of the base of UIRR Report (2012).

Table 9. The costs structure at different technologies and distances [\%]

\begin{tabular}{|l|r|r|r|r|r|r|}
\hline \multicolumn{1}{|c|}{ Distance $[\mathrm{km}]$} & \multicolumn{2}{|c|}{600} & \multicolumn{2}{c|}{800} & \multicolumn{2}{c|}{1000} \\
\hline Type of costs & $\begin{array}{c}\text { Fixed } \\
\text { costs }\end{array}$ & $\begin{array}{c}\text { Variable } \\
\text { costs }\end{array}$ & $\begin{array}{c}\text { Fixed } \\
\text { costs }\end{array}$ & $\begin{array}{c}\text { Variable } \\
\text { costs }\end{array}$ & $\begin{array}{c}\text { Fixed } \\
\text { costs }\end{array}$ & $\begin{array}{c}\text { Variable } \\
\text { costs }\end{array}$ \\
\hline "Piggy back" & 48 & 52 & 44 & 56 & 41 & 59 \\
\hline Modalohr Horizontal & 60 & 40 & 56 & 44 & 53 & 47 \\
\hline CargoBeamer & 55 & 45 & 52 & 48 & 48 & 52 \\
\hline
\end{tabular}

Source: own elaborations of the base of UIRR Report (2012). 


\section{CONCLUSIONS}

The intermodal transport can be competitive, even without state support, as long as certain conditions are met. From the calculations carried out by authors for the analysed connection, the fixed costs share in the total costs not much change depending on the distance. Hence, it may be suggested that scale is not important and that intermodal connections can be competitive even on shorter distances or in the case of lower volumes of goods. Yet according to calculations conducted by authors scale has an important impact on competitiveness of this form of transport, but the scale measured in volumes. According to the KombiConsult's study, when more than 2 pairs of trains are operated and their utilization level is $80 \%$, all three technologies offer rates below $1 € / \mathrm{km}$. So the volume of the transported cargo has important impacts on the competitiveness of intermodal connections. At the moment, such big volumes are unrealistic in the Eastern European markets.

Linking however, different regions, allows achieving lower costs, so differences of the costs in Western and Eastern regions of the European Union are relevant. But even when big differences ( 2 times lower costs in Eastern Europe) are taken into consideration, the Modalohr and Cargo Beamer are still more expensive than assumed $0,85 € / \mathrm{km}$. The reason being, that in the Authors' model, that costs of wagons are relatively high and the same as in the KombiConsult's study. This assumption seems reasonable as these technologies are innovative and require advanced technical solutions, which presently are not accessible in the countries of Eastern Europe, what means, that they would have to be bought from richer countries like Switzerland or Germany.

\section{REFERENCES}

Arendt, T., Seidelmann, Ch. (eds.) (2010). Analysis and Comparison for Intermodal Transport Chains in European Markets: Handling and Transport Techniques. January.

Arnold, P., Peeters, D., Thomas, I. (2004). Modelling a Rail/Road Intermodal Transportation System. Transportation Research Part E, 40 (3), 255-270.

Dărăbanț, S., Ștefănescu, P., Crișan, R. (2012). Economic Benefits of Developing Intermodal Transport in the European Union. Annals of the University of Oradea. Economic Science Series, 21 (2), 81-87.

Henttu, V., Multaharju, S. (2011). Transshipment Costs of Intermodal Transport in Finnish Context. Research Report. Faculty of Technology Management, Industrial Engineering and Management Tutkimusraportti Research Report 234. Kouvola.

Krasoń, W., Niezgoda, T. (2013). Koncepcja i wybrane aspekty badań wagonu kolejowego do przewozu naczep samochodów ciężarowych. Prace Naukowe Politechniki Warszawskiej. Transport, 98, 321-330

Macharis, C. (2000) Strategische modellering voor intermodale terminals. Socio-economische evaluatie an de locatie van binnenvaart/weg terminals in Vlaanderen. PhD Thesis. Brussel: Vrije Universiteit Brussel.

Nowakowski, T., Kwaśniowski, S., Zając, M. (2010). Transport intermodalny w aspekcie realizacji modelu systemu logistycznego polski. Prace Naukowe Politechniki Warszawskiej. Transport, 76, 103-111.

Starzyńska, D., Walasek, R. (2013). Koszty logistyczne w transporcie intermodalnym - wyniki badań. Logistyka, 2, 122-129.

UIRR Report (2012). Study on Unaccompanied Combined Transport of Semitrailers through Switzerland. Final report. European Road-Rail Combined Transport. KombiConsult GmbH. 30 November.

Vrenken, H., Macharis, C., Wolters, P. (2005). Intermodal Transport in Europe. Brussels: EIA.

Wiśnicki, B., Milewski, D. (2014). Analysis of the Market Potential for Transport Using the Longer and Heavier Vehicles in Poland. Logistyka, 6, 13923-13928. 
Zamkowska, S. (2013). Transport intermodalny szansą na zwiększenie udziału kolei w rynku. Autobusy. Technika, Eksploatacja, Systemy Transportowe, 3.

\section{Wpływ zróżnicowania regionalnych uwarunkowań gospodarczych na efektywność ekonomiczną transportu intermodalnego w Europie}

STRESZCZENIE | Celem artykułu jest zaprezentowanie problemu uruchamiania połączeń intermodalnych łączących dwa różne regiony europejskie, tj. rozwinięte gospodarczo i rozwijające się. Zidentyfikowano czynniki o charakterze technologicznym i ekonomicznym, które sprzyjają osiągnięciu pożądanej efektywności ekonomicznej transportu intermodalnego. Nierównowaga gospodarcza punktów nadania i odbioru przejawia się brakiem zbilansowania masy ładunkowej, brakiem jednolitych standardów technologicznych oraz różnicami w otoczeniu gospodarczym. W ramach badań przeprowadzono analizę kosztów trzech technologii szynowo-drogowych do przewozu naczep siodłowych. Analizowane parametry dotyczyły odległości przewozu, kosztów inwestycyjnych i eksploatacyjnych, przewożonej masy ładunkowej. Przeprowadzone obliczenia pozwoliły na sformułowanie wniosków i rekomendacji dotyczących warunków koniecznych i wspomagających, które powinny zostać spełnione, aby transport intermodalny mógł skutecznie konkurować z transportem drogowym.

SŁOWA KLUCZOWE

Translated by Dariusz Milewski and Bogusz Wiśnicki 